\title{
Socio-Ecological System within Governance of Marine Protected Area: Case from Cenderawasih Bay National Park, Indonesia
}

\author{
Roni Bawole $^{1 *}$, Fredinan Yulianda ${ }^{2}$, Dietriech Geoffrey Bengen ${ }^{3}$, Achmad Fahrudin $^{2}$, Mudjirahayu $^{4}$
}

\author{
${ }^{1}$ Department of Marine Sciences, Faculty of Fishery and Marine Sciences, University of Papua, Manokwari 98314 \\ ${ }^{2}$ Department of Aquatic Resources Management, Faculty of Fishery and Marine Science, Bogor Agricultural University, \\ Academic Ring Road, Campus IPB Dramaga, Bogor, Indonesia 16680 \\ ${ }^{3}$ Department of Marine Science and Technology, Faculty of Fisheries and Marine Science, Bogor Agricultural University, \\ Academic Ring Road, Campus IPB Dramaga, Bogor, Indonesia 16680 \\ ${ }^{4}$ Department of Fisheries, Faculty of Fishery and Marine Sciences, University of Papua, Manokwari 98314
}

\section{Received February 25, 2015/Accepted April 25, 2015}

\begin{abstract}
Overcoming the problem of resource management which relies only on social dimension without understanding the ecosystem dynamics will not be sufficient to create sustainable management. Therefore, socio-ecological system $(S E S)$ is needed to respond changes so that robust management could be created. Research on SES was focused more on capacity of governance in creating management of conservation area, particularly in the period where there were occurrence of resistance between social problem and ecosystem. Principal component analysis explained 76\% of the total variability. Very high variable respond category occurred on first principal component (PC) with positive effect which was related directly to ecological condition, and negative effect toward catch yield and utilization of traditional zone. Condition of economy and fish resources contributed positively toward second PC, and can be expressed as factor which affected economic condition of fishermen household. Condition offishermen, related with catching activity and income of fishermen household gave positive effect toward the third PC, and can be expressed as component which affected catching effort and explained exploitation level by fishermen toward resources. Interaction between factors which formed SES occurred due to economic activity of fishermen household, catching efforts, and ecological capacity. Design of governance could be conducted on increase of fishermen household economy through control of catching efforts and considering the carrying capacity and ecological capacity.
\end{abstract}

Keywords: governance, socio-ecological system, marine protected areas, sustainable management

*Correspondence author, email: ronibawole@yahoo.com,tel.+62-8124830507

\section{Introduction}

Universally, human activities have been intensified by various progresses of technology, global market, and governance system. Human's decision in a particular place will affect human beings in other place. Meanwhile, environmental capacity (locally and globally) to create community development has deteriorated quantitatively and qualitatively from time to time (Jackson et al. 2001). This phenomenon caused environmental capacity in various regions became very limited in fulfilling human's need (Folke et al. 2004). This condition has encouraged the use of management approach on ecosystem basis, become the primary basis for protecting and conserving natural resources, including coastal areas and sea.

Various researches reveal that socio-ecological system (SES) possesses strong feedback input and could operate in complex adaptive system in resource management (Berkes et al. 2003). This phenomenon is important to explain that implication of joint analysis of SES is very different with social system and ecological system which are analysed separately (Ludwig et al. 2001; Anderies et al. 2004). Overcoming the problem of natural resource management which relies only on social dimension without understanding the ecosystem dynamics will not sufficient to achieve sustainable management (Folke et al. 2005). Therefore, there is a need for sufficient capacity of SES to respond to changes, so that strong and proper management could be created.

Governance is defined as a structure and process which people in community make decision and share power (Lebel et al. 2006). Advocation of governance approach constitutes a process of trade off problem solving which allows SES to work optimally in creating sustainability of resource utilization (Folke et al. 2005). Therefore, SES not only solve the problem of capacity of stakeholders, but it also deals with change and disturbance of environmental quality deterioration. Dietz et al. (2003) used the concept of governance in extending the approach of ecosystem management so that social problems could be solved and allow ecosystem management to run properly. 
As conservation area, Cenderawasih Bay National Park (CBNP) has been managed in centralistic manner since the year 1989 through management authority of CBNP under Forestry Ministry, Republic of Indonesia (Bawole et al. 2012). Various problems have arisen in relation with CBNP management and this problem could be found in various studies; resolution of management conflict (Sembiring et al. 2010); analysis of stakeholders (Bawole 2012), and development of ecotourism (Siregar 2011; Ekayani \& Nuva 2013). Problems of management are caused more by limited capacity of the management, lack of understanding and support from various related institutions, lack of community involvement in conservation efforts and weak coordination between institutions. In overcoming such various problems, there is a need for development of management conflict which could unite the various interests in utilizing resources. Several researchers recommended the application of governance in good management practices (Bawole et al. 2011), adaptive and collaborative management for accommodating various interests (Nurrochmat 2005a; Nurrochmat 2005b; Bawole et al. 2012; Nurrochmat et al. 2012;) and the need for considering multidimensional integration in creating good management performance (Marwa et al. 2010; Bawole et al.2013). Besides application of the various approaches, application of conservation area management on the basis of SES could also become an option in overcoming bottleneck in management problem. Application of SES requires integration of various biophysical components, including those of environment and socioeconomics, issues related with local attitude, and change of life quality. Those components possess limitation in supporting the utilization of fishery resources. Development activities which exceed environment carrying capacity will lead to environmental degradation or social conflict.

SES in this research was put in the framework of management on ecosystem basis, such as for exploring SES from adaptive governance system. SES is focused more on governance capacity in creating management of marine conservation area, particularly in the period when resistance occurs between social problem and ecosystem problem. Therefore, governance design becomes an option which is able to develop and establish internal SES resistance in relation with facing the external (driven) stimulating factors. This research also revealed how the social aspects of fishermen became significant in facing the change and disturbance of ecosystem.

\section{Methods}

Research location was CBNP area which was located in administrative area of Regency of Teluk Wondama, and was carried out in October 2010-June 2011. Research location comprised 5 districts from the 13 districts existing in Regency of Wondama Bay (Figure 1). Five districts (Rumberpon, Roswar, Windesi, Wasior, and Roon) were places for data collection and constituted the coastal districts. These locations were determined in purposive sampling (Cochran 1977) by considering the location (position of island and the mainland of Papua), community access toward coastal resources and accessibility of product marketing.
Wasior and Windesi constituted the research locations which were situated in the mainland of Papua Island and were categorized as areas which have access to market. Even, Wasior constituted the location of the capital of Wondama Bay Regency and served as area for fish landing. Rumberpon, Roswar, and Roon constituted the location which represented the location which had limited access to market, so that these locations became relevant as complement for areas which functioned as fish landing places. In these locations there were local collecting traders which were able to collect the fishermen catch in the form of salted fish.

Collection of household samples from each kampong was conducted on the basis of proportion of fishermen households within the total number of households (Yulianda et al. 2010). Total number of respondents was 190 households comprising 22-45 fishermen households from each kampong within 5 districts (Rumberpon, Roswar, Windesi, Wasior, and Roon). Number of respondent depended very much on population of residents in the kampong, time availability per location (because it was affected very much by weather, availability and frequency of definite transportation in each location), and the cost which included accommodation cost during the survey).

An interview was conducted with the head of household (family head). If the family head was absent, this household was be interviewed at other time, and if the family head was still absent at the other time, then the household lady or the oldest child (adult) was interviewed. Respondents were questioned on the basis of questionnaire. The questions comprised of inquiry on their participation in decision making process, participation in group, income, knowledge concerning fishery activities (coral reef), fish catching activities, and perception of respondents toward management activities (Table 1).

Data were analyzed using factor analysis with method of principal component analysis (PCA) (Digby \& Kempton 1987) to determine the total number of factors being involved, while contribution of variables which were relatively small, were neglected in the analysis. Similar techniques were used to determine the knowledge scale of the community concerning reef fishery. Open-ended questions were used for examining the community perception which had positive and negative effect toward SES. PCA was used to reduce large number of variables, but the result of reduction possessed large contribution in determining SES governance. Scale of SES was developed on the basis of interaction between criteria factors which formed the SES and was analyzed with PCA.

\section{Results and Discussion}

Components of SES Tracing of factors (variables) which affected the socio-ecological condition of reef fishery used PCA and the analysis results were able to explain $76 \%$ of the total variability. Very high variable respond category occurred in the first principal component (PC) with positive effect directly related with ecological condition, and negative effect toward result of catch and traditional zone utilization. This negative effect was related with high catch yield (target fish) under low reef cover condition. The PC1 could be said 


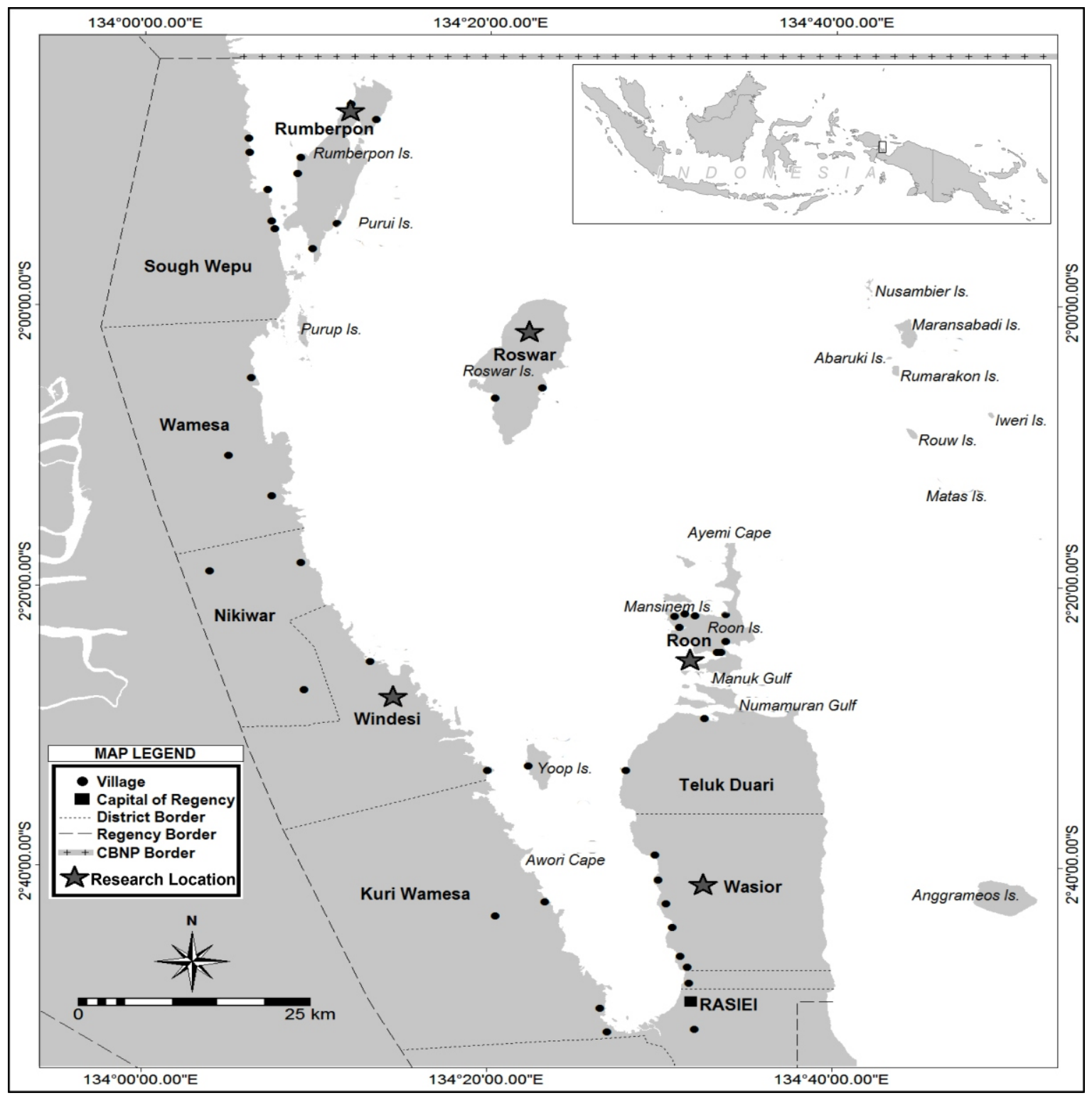

Figure 1 Research location.

Table 1 Description of variables

\begin{tabular}{ll}
\hline \multicolumn{1}{c}{ Variables } & \multicolumn{1}{c}{ Description } \\
\hline Condition of fish resources & $\begin{array}{l}\text { Level of fish catching activities which is conducted by the fishermen, for instance by } \\
\text { inquiring whether there was still sufficiently abundant fish in their catching area? }\end{array}$ \\
Catching efforts & $\begin{array}{l}\text { Perception of the fishermen toward the number of fishermen who conducted fish catching } \\
\text { activities within their traditional catching area, for instance by inquiring respond from } \\
\text { question "how if the number of fishermen was increased } 2 \text { folds, } 3 \text { folds, etc. }\end{array}$ \\
Yield of catch & Amount of fishermen' catch each day. \\
Zone of traditional utilization & Description of allocation of traditional utilization zone in ensuring the fishermen activities. \\
Effect on household economy & Impact of CBNP management activities on the economy of fishermen household. \\
Ecological effect of core zone & Ecological impact of traditional utilization zone in ensuring fish catching activities due to the \\
establishment of no fish catching area in core zone.
\end{tabular}


as collection of factors which affected fish in marine conservation area (Table 2).

Condition of economic and fish resources contributed positively toward the second (PC2) and can be expressed as factor which affected the economic condition of the fishermen household. Fishermen condition was related with catching activities and income of fishermen household gave positive effect toward the third (Pc3), and can be expressed as component which affected the effort of catching and explained the exploitation level by fishermen toward the resources.

The interesting phenomenon which could be shown from the analysis above was that the PC3 were highly associated with capacity of the community in utilizing resources and ecological condition of the marine conservation area. This was related with the effect of economic activity of fishermen household toward marine resources. In the context of SES, interaction between factors which form SES occurred due to economic activity of fishermen household, catching efforts, and ecological capacity. This analysis result was supported by $64 \%$ respondents who said that fishes were still abundant in the sea, $14 \%$ respondents said that fishes were in moderate category, while only $23 \%$ who said that fishes were in the category of few/rare. Afterwards, $79 \%$ respondents said that fishes were still easy to be caught/captured.

Research results showed that in general, 95\% of the fishermen had income level which was categorized as low (IDR104,583 $\pm 85,675$ per month), and only $5 \%$ of the fishermen had high income (IDR1,183,333 $\pm 275,379$ per month). Manembu (2008) explained that fishermen household income in Teluk Cenderawasih were between IDR500,000-3.000.000 per month. This income varied in accordance with condition of waters, season/frequency of catch, and access to product market. This low income level was due to production facilities which were still very simple, extent of catching area which were still limited and the general reliance on shallow waters which were near with human settlement. This condition was also exacerbated by low selling value of the product, due to considerably high dependence of the fishermen on local traders (middlemen). This was due to lack of other choices in marketing the yield of catch. Isolation of the area and limited accessibility of transportation made the farmers or community difficult to market their catch.

Fishermen households constitute a community which faces varying socio-ecological challenge and opportunity. This was the result of development of their ability in facing natural challenge and economic opportunity which emerged incidentally. Economic opportunity was created when there were collecting traders who purchased their catch. The presence of these collecting traders is a strategic issue and serve as one chain in the trading system of fishery product. However, these traders could also be a problem source because at kampong or district level, fish price was still low as compared with price in the capital of the regency (Wasior) and other closely regencies (Manokwari and Nabire).

Fishermen, either as individual and group, possess difference in terms of socio-economic aspect as compared with other communities (farmers, merchant, government civil servants). In particular, fishermen possess high concern and good opinion in affecting and improving resources in the marine protected areas (MPA). This phenomena could be seen from their involvement in decision making process, and some of them have alternative jobs (farming, plantation, and hunting). Research results showed that around $56 \%$ of the respondents were involved in conservation activities, both individually and institutionally. They were associated in group of conservation cadres which was formed by management authority of CBNP in each district or kampong of coastal areas.

High involvement of fishermen or group in conservation activities and decision making process, as shown in this research was not in agreement with research results from Cinner et al. (2010) which reported that fishermen were rarely involved in decision making process and were politically weak. Involvement of fishermen in the management of CBNP was related with their seriousness and concern to overcome the damage of coastal resources. Fishermen often formed groups and build temporary residential area (fishing camp) to catch fish while also controlling the coastal land. For example, fishermen from Roon Island conducted fish catching in Auri Islands (1-2 weeks), because those islands were under the customary right of Roon residents.

Although the coastal community people have low education level, they were able to mention directly the factors which could affect the quantity of fishes in marine protected areas. Research results showed that around 76\% of the respondents stated that the established zonation could maintain the ecological condition of the area and could

Table 2 Principal Component Analysis of socio-ecological system

\begin{tabular}{lccc}
\hline \multicolumn{1}{c}{ Variable } & PC 1 & PC 2 & PC 3 \\
\hline Condition of fish resources & -0.3037 & $\mathbf{0 . 6 5 2 7}$ & -0.1286 \\
Condition of fishermen & 0.0804 & 0.5193 & $\mathbf{0 . 7 6 1 5}$ \\
Yield of catch & $\mathbf{- 0 . 6 7 7 5}$ & 0.0101 & 0.1528 \\
Zone of traditional utilization & $\mathbf{- 0 . 6 1 5 1}$ & 0.0600 & 0.2464 \\
Effect of household economy & 0.5881 & $\mathbf{0 . 6 0 4 1}$ & -0.0256 \\
Ecological effect of core zone & $\mathbf{0 . 7 5 3 5}$ & -0.0110 & -0.0351 \\
Income & -0.3034 & 0.4833 & $\mathbf{0 . 6 4 7 0}$ \\
\hline
\end{tabular}

Bold marked possess high effect $(>0.6)$ compared with Cinner et al. (2010) who used value $>0.4$ 
protect the fish resources. Respondents could also be requested to discuss problems of coastal ecosystem damage and improvement of household economy. As many as $82 \%$ of respondents said that the existing fishes in the sea depended on existing ecosystem around the habitat (reef, seagrass and mangrove), and around $72 \%$ of respondents said that their household economy depended very much on fish resources. As for example, fishermen will be serious in discussing the activities of fish bombing and fish stunning if they were related with degradation of coral reef and long term impact toward their income in the future. These research results were similar with that of a research in Kenya which showed that fishermen possessed high concern in management of marine resources (Evans 2010). This condition was possibly somewhat different with that of general fishermen in Indonesia, as had been put forward by Hendratmoko and Marsudi (2010). These 2 researchers explained that in general, coastal community in Indonesia constitutes a community group which was socially, economically, and culturally, relatively underdeveloped as compared with other community groups. Continuous flow of information from staffs of management authority of CBNP and NGOs in utilizing marine resources in sustainable manner, has caused change in the habit of fish catching. Core zone has been intentionally adopted by the community by mentioning it as "fish saving" for future period. This zone could ensure the sustainability of resources within the zone of traditional utilization areas for fish catching by the community.

The creation of fish market due to the presence of local collecting traders and buyers from outside of Wondama Bay will change the orientation of resource utilization into more intensive one. In this case, fishermen who were initially passive in catching fish will be more active and will in turn increase household income. However, if this fish catching activities are not controlled, this will create negative impact on resource in the conservation area. Intervention of utilization regulation should be conducted to put all activities in order so that fish catching will not cause damage on habitat and target biota biomass.

Governance of SES Analysis of SES, as has been described above showed that factors which formed SSE were determined very much by economic activity of fishermen household, catching efforts and ecological capacity. Therefore, governance of SES could be conducted through intervention of management activities on increase of fishermen household economy, fish catching efforts and improvement of ecological environmental quality, particularly the coral reef ecosystem. Bawole et al. (2013) showed that ecological dimension need to get serious attention in creating sustainable reef fisheries in the area of CBNP. Governance approach through SSE could be used as instrument for overcoming the socio-economic and ecological trade off (Folke et al. 2005). This condition allows SSE to work optimally in creating the sustainability of resource utilization while also increasing the socio-economic capacity. Therefore, SSE not only handle the problem stakeholder capacity, but also handle change and disturbance of environmental quality deterioration. Dietz et al. (2003) showed that intervention of governance could widen the approach of ecosystem management so that social problems could be overcome and allow ecosystem management to run properly.

The capacity to adapt to and shape change is an important component of a social-ecological system. In a socialecological system with high adaptability, the actors have the capacity to reorganize the system within desired states in response to changing conditions and disturbance events. Adaptive management is often put forward as a more realistic and promising approach to deal with ecosystem complexity than management for optimal use and control of resources. Dietz et al. (2003) used the concept of adaptive governance to expand the focus from adaptive management of ecosystems to address the broader social contexts that enable ecosystem-based management. By governance, we mean creating the conditions for ordered rule and collective action or institutions of social coordination. Governance is the structures and processes by which people in societies make decisions and share power. Advocating an adaptive socialecological system into governance can be applied by a triad of activities, wherein governance is the process of resolving trade-offs and of providing a vision and direction for sustainability, management is the operationalization of this vision, and monitoring provides feedback and synthesizes the observations to a narrative of how the situation has emerged and might unfold in the future.

\section{Conclusion}

Integration between factors which formed the SES was determined by economic activity of fishermen household, efforts of fish catching, and ecological capacity. Capacity of governance in the management of marine conservation is needed in the period when there is resistance between social problem and ecosystem. Design of governance can be conducted on increase of fishermen household economy through efforts of control of fish catching and considering the carrying capacity and ecological capacity. Therefore, intervention of governance is able to develop and form resistance of SES in creating management of marine conservation area.

\section{References}

Anderies JM, Janssen MA, Ostrom E. 2004. A framework to analyze the robustness of social-ecological systems from an institutional perspective. Ecology and Society 9(1):18. [online] URL: http://www.ecologyandsociety.org/vol9/ iss $1 / \operatorname{art} 18$.

Bawole R, Rumere R, Mudjirahayu, Pattiasina TP. 2013. Performance of coral reef management: Integrating ecological, socioeconomic, technological, and institutional dimensions. Jurnal Manajemen Hutan Tropika 19(1):63-73. http://dx.doi.org/10.7226/jtfm. 19.1.63.

Bawole R, Yulianda F, Bengen DG, Fahrudin A. 2011. Governance sustainability of traditional use zone within Marine Protected Area National Park of Cenderawasih Bay, West Papua. Jurnal Manajemen Hutan Tropika 17(2):71-78. 
Bawole R, Yulianda F, Bengen DG, Fahrudin A. 2012. Collaborative management of traditional use zone of Cenderawasih Bay National Park. Jurnal Pesisir dan Pulau Pulau Kecil 1(1):73-86.

Bawole R. 2012. Analysis and mapping of stakeholders in traditional use zone within marine protected area. Jurnal Manajemen Hutan Tropika 18(2):110-117. http://dx.doi.org/10.7226/jtfm.18.2.110.

Berkes F, Colding J, Folke C. 2003. Navigating SocialEcological Systems: Building Resilience for Complexity. Cambridge: Cambridge University Press.

Cinner JE, McClanahan TR, Wamukota A. 2010. Differences in livelihoods, socioeconomic characteristics, and knowledge about the sea between fishers and non-fishers living near and far from marine parks on the Kenyan coast. Marine Policy 34:22-28. http://dx.doi.org/10. 1016/j.marpol.2009.04.003.

Cochran WG. 1977. Sampling Techniques. Third edition. New York: John Willey \& Sons.

Dietz T, Ostrom E, Stern PC. 2003. The struggle to govern the commons. Science 302:1902-1912. http://dx.doi.org/10. 1126/science.1091015.

Digby PG, Kempton RA. 1987. Multivariate Analysis of Ecological Communities. New York: Chapman and Hall. http://dx.doi.org/10.1007/978-94-009-3135-0.

Ekayani M, Nuva. 2013. Economics of ecotourism. In: Kim S, Kang, Sukmajaya, editors. Opportunities and Challenges of Ecotourism in ASEAN Countries. Seoul: Jungmin Publishing Co.

Evans LS. 2010. Ecological knowledge interactions in marine governance in Kenya. Ocean and Coastal Management. 53(4):180-191 http://dx.doi.org/10.1016/ j.ocecoaman.2010.01.009.

Folke C, Carpenter S, Walker B, Scheffer M, Elmqvist T, Gunderson L, Holling CS. 2004. Regime shifts, resilience, and biodiversity in ecosystem management. Annual Review of Ecology, Evolution, and Systematics 35:557-581. http://dx.doi.org/10.1146/annurev.ecolsys. 35.021103.105711.

Folke C, Hahn T, Olsson P, Norberg J. 2005. Adaptive governance of social-ecological systems. Annual Review of Environment and Resources 30:441-473. http://dx.doi. org/10.1146/annurev.energy.30.050504.144511.

Hendratmoko Ch, Marsudi H. 2010. Analisis tingkat keberdayaan sosial ekonomi nelayan tangkap di Kabupaten Cilacap. Dinamika Sosial Ekonomi 6:1-17.

Jackson JBC, Kirby MX, Berger WH, Bjorndal KA, Botsford LW, Bourque BJ, Bradbury RH, Cooke R, Erlandson J, Estes JA, Hughes TP, Kidwell S, Lange CB, Lenihan HS, Pandolfi JM, Peterson CH, Steneck RS, Tegner MJ,
Warner RR. 2001. Historical overfishing and the recent collapse of coastal ecosystems. Science 293(5530): 629-638. http://dx.doi.org/10.1126/science. 1059199.

Lebel L, Anderies JM, Campbell B, Folke C, Hatfield-Dodds S, Hughes TP, Wilson J. 2006. Governance and the capacity to manage resilience in regional socialecological systems. Marine Sciences Faculty Scholarship 11(1):52. http://digitalcommons.library. umaine.edu/sms_facpub/52.

Ludwig D, Mangel M, Haddad B. 2001. Ecology, conservation, and public policy. Annual Review of Ecology, Evolution, and Systematics 32:481-517. http://dx.doi.org/10.1146/annurev.ecolsys.32.081501.11 4116.

Manembu A. 2008. Socio economic baseline survey Cenderawasih Bay National Park Papua and West Papua Province. Papua: WWF Papua.

Marwa J, Purnomo H, Nurrochmat DR. 2010. Managing the last frontier of Indonesian forest in Papua. Bogor: AKECOP-IPB.

Nurrochmat DR. 2005a. Strategi Pengelolaan Hutan: Upaya Menyelamatkan Rimba yang Tersisa. Yogyakarta: Pustaka Pelajar.

Nurrochmat DR. 2005b. The Impacts of Regional Autonomy on Political Dynamics, Socio-Economics and Forest Degradation. Case of Jambi-Indonesia. Göttingen: Cuvillier Verlag.

Nurrochmat DR, Hasan MF, Suharjito D, Hadianto A, Ekayani M, Sudarmalik, Purwawangsa H, Mustaghfirin, Ryandi ED. 2012. In: Nurrochmat DR, Hasan MF, editors. Ekonomi Politik Kehutanan. Mengurai Mitos dan Fakta Pengelolaan Hutan. Second Edition, revised 326 version. Jakarta: INDEF.

Sembiring S, Basuni S, Soekmadi R. 2010. Conflict resolution of Teluk Cenderawasih National Park Management in Teluk Wondama Regency. Jurnal Manajemen Hutan Tropika 16(2): 84-91.

Siregar M. 2011. Peranan Stakeholders terhadap Pengembangan Ekowisata di Taman Nasional Teluk Cenderawasih Kabupaten Teluk Wondama Provinsi Papua Barat. (Thesis). Bogor: Sekolah Pascasarjana Institut Pertanian Bogor.

Waltner-Toews D, Kay JJ, Neudoerffer C, Gitau T. 2003. Perspective changes everything: managing ecosystems from the inside out. Frontiers in Ecology and the Environment 1(3):23-30. http://dx.doi.org/10. 1890/1540-9295(2003)001[0023: PCEMEF]2.0.CO;2.

Yulianda F, Fachrudin A, Hutabarat AA, Harteti S, Kusharjani. 2010. Pengelolaan Pesisir dan Laut Secara Terpadu. Jakarta: Departemen Kehutanan Republik Indonesia. 